\title{
Epiphytic lichens as indicator of land-use pattern and forest harvesting in a community forest in west Nepal
}

\author{
Pramod Nag ${ }^{1 *}$, Himanshu Rai ${ }^{2,3}$, Dalip Kumar Upreti ${ }^{2}$, Sanjeeva Nayaka ${ }^{2}$ and \\ Rajan Kumar Gupta ${ }^{3}$
}

${ }^{1}$ Department of Botany, Mahendra Multiple Campus, Tribhuvan University, Nepalgunj, Banke-21900, Nepal; ${ }^{2}$ Lichenology Laboratory, National Botanical Research Institute, CSIR, Lucknow, Uttar Pradesh-226001, India; ${ }^{3}$ Department of Botany Pt. L.M.S. Government Post Graduate College, Rishikesh (Dehradun), Uttarakhand-249201, India

\begin{abstract}
Human inhabitance and agriculture have fundamentally altered global pattern of biodiversity and ecosystem processes. Therefore, integration of community-based approach is an effective conservation strategy. Community forestry is an important community-based approach, which can help in conserving local ecological assets in a sustainable manner. Lichens are known to be more sensitive indicators of ecosystem functions and disturbances than any other cryptogam and vascular plant community. Present study reports a preliminary assessment of epiphytic lichens in a community forest in Dadeldhura district, west Nepal, in order to identify potential indicator of forest health and land-use pattern. Epiphytic (corticolous) lichens were sampled from ten land-use units (LUU), using narrow frequency grids of $10 \mathrm{~cm} \times 50 \mathrm{~cm}$, each divided into five sampling units of $10 \mathrm{~cm} \times 10 \mathrm{~cm}$, on the bark of selected tree species. Quercus leucotrichophora was the dominant phorophyte followed by Pinus roxburghii, Rhododendron arboreum and Myrica esculenta. Foliose parmeloid (Parmotrema spp., Heterodermia spp., Hypotrachyna spp., Bulbothrix spp., Canoparmelia spp., Canomaculina spp.) was the most abundant lichen group, found inhabiting all the phorophytes followed by crustose, fruticose and dimorphic growth forms. Maximum diversity of parmeloid lichens was recorded on older stand of Quercus while younger stands usually harbored crustose lichens (e.g., Lecanora spp., Basidia spp.). Though the lichen diversity increased from outer fringes of the forest to the core, the vegetation stand age was not distributed in any consistent pattern suggesting unconstrained harvesting of the forest. Lichen diversity was found constrained by phorophyte determinants (stand age, aspect, and bark properties) and community harvesting of the forest.
\end{abstract}

Key-words: biodiversity, community forestry, parmeloid, phorophytes.

\section{Introduction}

Human exploitation of natural resources has reached to such an extent that its own livelihood is on stake. Intrusive resource management strategies (i.e. protected areas, sanctuaries, national parks), which usually restrict local inhabitants from forest resources, have shown that consideration of local community in biodiversity conservation is inevitable (Agrawal

*Correspondence,

e-mail: nagpramod10@yahoo.com; Tel: +9779848024422. and Gibson 1999; Dougill et al. 2001; Berkes 2007). Community forestry can help sustainable management of forest resources and can play a key role in conservation of biodiversity of the region.

Lichen species, although have wider distribution than vascular and other cryptogams, are influenced greatly by changes in land-use (Stofer et al. 2006). Epiphytic lichens are widely used as bioindicators of atmospheric pollutants and change in environmental conditions (Nimis et al. 2002; WillWolf et al. 2002a,b; Saipunkaew et al. 2007). Epiphytic lichen 


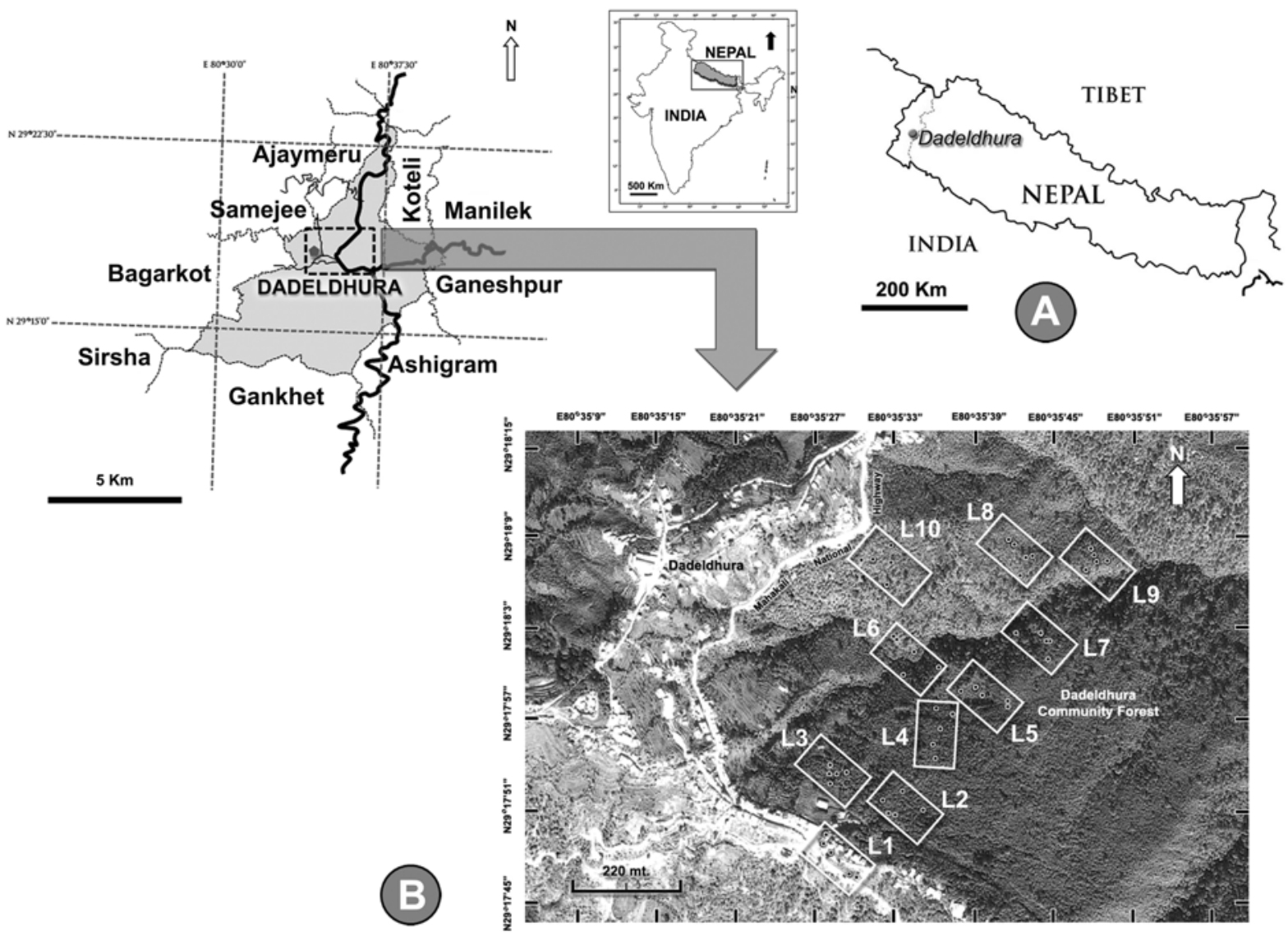

Figure 1. Map of the study area. (A) Location map; (B) Location of land-use units sampled in Dadeldhura Community Forest (adapted from Google Earth 2007, downloaded on 1 Nov 2010).

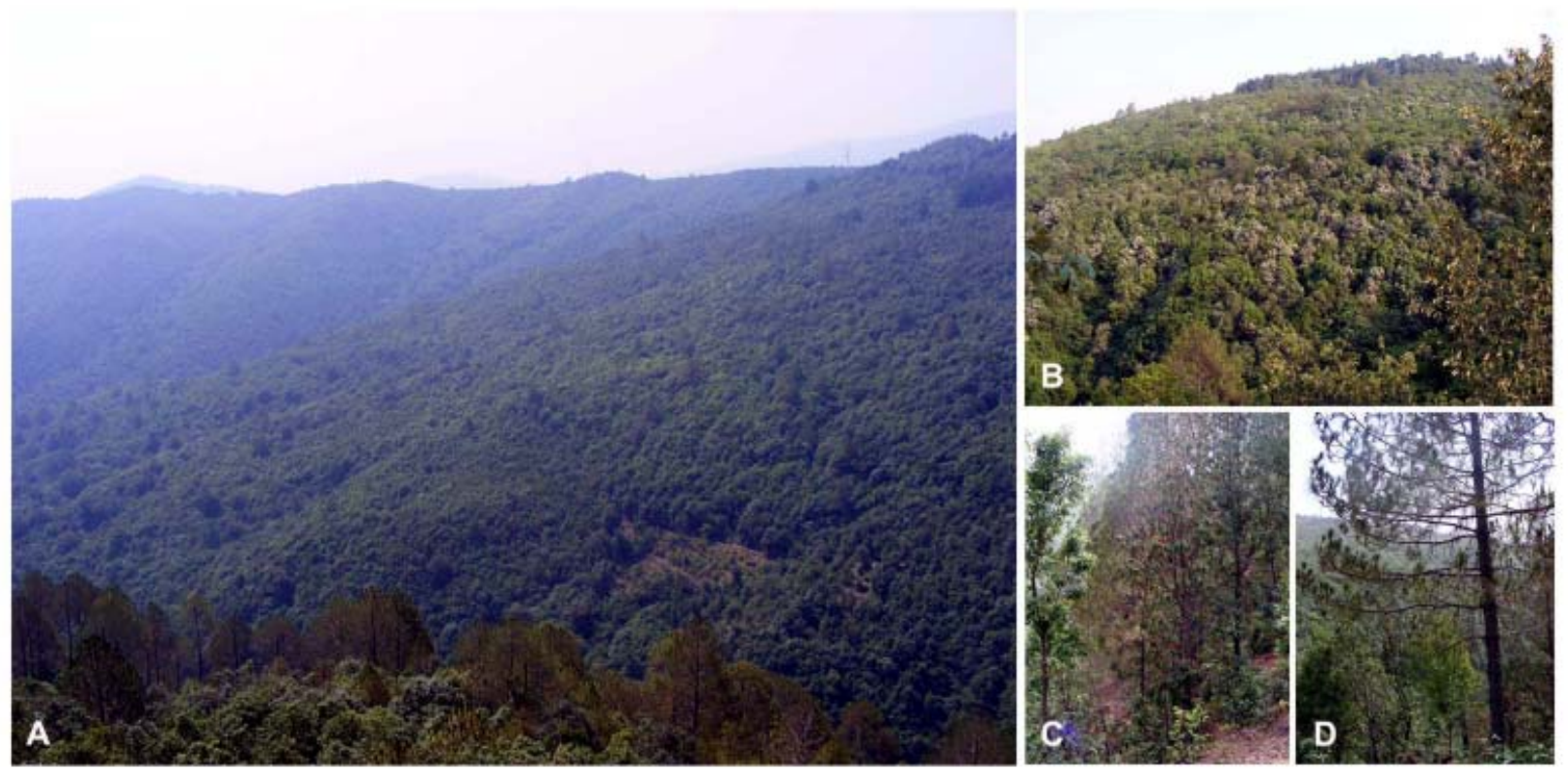

Figure 2. Phorophyte diversity in Dadeldhura Community Forest. (A) Overview of the forest; (B) Quercus leucotrichophora stand; (C) Rhododendron arboreum stand; (D) Pinus roxburghii stand. 
diversity is found variously influenced by phorophyte age, ambient air quality, and change in neighborhood land-cover (Saipunkaew et al. 2005; Pinho et al. 2008; Thomas et al. 2008). The indicator value of epiphytic lichens can be attributed to general structural peculiarities of lichen thallus (i.e. absence of waxy cuticle, absence of root and absorption of water and nutrients passively from the environment) and microhabitat sensitivity (Will-Wolf et al. 2002a,b).

Present study reports a preliminary assessment of epiphytic (corticolous) lichens in a community forest of West Nepal in order to identify elements in lichen-phorophyte complex, depicting over all forest health and land-use pattern.

\section{Materials and Methods}

\author{
STUDY AREA
}

This study was conducted in Dadeldhura Community Forest (CF) extending between $29^{\circ} 18^{\prime} 9^{\prime \prime}$ to $29^{\circ} 17^{\prime} 45^{\prime \prime} \mathrm{N}$ latitude and $80^{\circ} 35^{\prime} 21$ "to $80^{\circ} 35^{\prime} 51^{\prime \prime}$ E longitude within Dadeldhura Village Development Committee (VDC) area in Dadeldhura district, Mahakali zone, west Nepal (Figure 1). Studied area shows altitudinal variation of 1600 to $1800 \mathrm{~m}$ above sea level (asl). Climate of the area is influenced by summer monsoon. The area is characterized by an average maximum annual temperature of $30^{\circ} \mathrm{C}$ to a minimum of $4^{\circ} \mathrm{C}$ and an average

Table 1. List of epiphytic (corticolous) lichen genera, their growth form and frequency in different phorophytes in Dadeldhura CF.

\begin{tabular}{|c|c|c|c|c|c|c|}
\hline \multirow[t]{2}{*}{ Lichen Genera } & \multirow[t]{2}{*}{ Family } & \multirow[t]{2}{*}{ Growth form* } & \multicolumn{4}{|c|}{ Frequency of lichens in different phorophytes ${ }^{\ddagger}$} \\
\hline & & & Ql & $\mathrm{Ra}$ & $\operatorname{Pr}$ & $\mathrm{Me}$ \\
\hline Bacidia (Ba) & Ramalinaceae & $\mathrm{Cr}$ & 2.58 & - & - & - \\
\hline Bulbothrix (Bu) & Parmeliaceae & Fo & 2.58 & 0.64 & - & 1.39 \\
\hline Candelaria (Cd) & Candelariaceae & Fo & - & - & 1.39 & - \\
\hline Canomaculina $(\mathrm{Cn})$ & Parmeliaceae & Fo & 0.64 & - & - & - \\
\hline Canoparmelia (Cp) & Parmeliaceae & Fo & 1.39 & - & - & - \\
\hline Chrysothrix (Cr) & Chrysothricaceae & $\mathrm{Lp}$ & 3.22 & - & 1.93 & - \\
\hline Cladonia $(\mathrm{Cl})$ & Cladoniaceae & $\mathrm{Dm}$ & - & 2.58 & - & - \\
\hline Cryptothecia (Cy) & Arthoniaceae & $\mathrm{Cr}$ & 0.64 & - & - & - \\
\hline Dirinaria (Dr) & Caliciaceae & Fo & 0.64 & - & - & - \\
\hline Graphis (Gr) & Graphidaceae & $\mathrm{Cr}$ & 3.22 & - & - & 1.39 \\
\hline Herpothallon $(\mathrm{Hr})$ & Arthoniaceae & $\mathrm{Cr}$ & 0.64 & - & - & - \\
\hline Heterodermia(Ht) & Physciaceae & Fo & 10.92 & 1.39 & 0 & 1.39 \\
\hline Hypotrachyna (Hy) & Parmeliaceae & Fo & - & 0.64 & 0.64 & - \\
\hline Lecanora (Lc) & Lecanoraceae & $\mathrm{Cr}$ & 5.12 & 1.39 & - & 2.58 \\
\hline Lepraria (Lr) & Stereocaulaceae & Lp & 8.38 & 1.93 & 1.39 & 1.39 \\
\hline Leptogium (Lt) & Collemataceae & Fo & 2.58 & - & - & - \\
\hline Myelochroa (My) & Parmeliaceae & Fo & 1.93 & - & - & - \\
\hline Parmelinella $(\mathrm{Pr})$ & Parmeliaceae & Fo & 0.64 & 0.64 & - & - \\
\hline Parmotrema (Pm) & Parmeliaceae & Fo & 14.83 & 1.93 & 0.64 & - \\
\hline Phaeophyscia(Ph) & Physciaceae & Fo & 1.93 & - & 0.64 & - \\
\hline Phyllopsora (Ph) & Ramalinaceae & $\mathrm{Cr}$ & 2.58 & - & - & - \\
\hline Physcia (Py) & Physciaceae & Fo & 2.58 & - & 0.64 & - \\
\hline Pyxine (Px) & Caliciaceae & Fo & 0.64 & - & - & - \\
\hline Ramalina $(\mathrm{Rm})$ & Ramalinaceae & Fr & - & - & - & 0.64 \\
\hline Rinodina (Rd) & Physciaceae & $\mathrm{Cr}$ & 3.21 & - & - & 0.64 \\
\hline Stictis (St) & Stictidaceae & $\mathrm{Cr}$ & 0.64 & - & - & - \\
\hline Usnea (Us) & Parmeliaceae & Fr & 0.64 & - & - & - \\
\hline Total frequency & & & 72.17 & 11.14 & 7.27 & 9.42 \\
\hline
\end{tabular}

${ }^{*} \mathrm{Cr}=$ Crustose, $\mathrm{Lp}=$ leprose, Fo = foliose, $\mathrm{Fr}=$ fruticose, $\mathrm{Dm}=$ dimorphic.

${ }^{\ddagger} \mathrm{Ql}=$ Quercus leucotrichophora, $\mathrm{Ra}=$ Rhododendron arboreum, $\mathrm{Pr}=$ Pinus roxburghii, $\mathrm{Me}=$ Myrica esculenta . 
annual precipitation of $121 \mathrm{~mm}$, with highest precipitation in the months of July-August. Vegetation of the area is classified as temperate and alpine broad leaved forests. Dadeldhura CF has a mixed temperate forest having dominance of Quercus leucotrichophora with patches of Pinus roxburghii on the fringes of the forest (Figure 2). Other prominent phorophytes were Rhododendron arboreum and Myrica esculenta.

\section{FIELD METHODS AND DATA RECORDING}

Epiphytic lichens were randomly sampled from ten land-use units (LUU) (each with $110 \mathrm{~m} \times 90 \mathrm{~m}$ ), distributed all over the landscape: human settlement (L1), fringe forest (L2 and L10), agricultural field (L3), primary forests (L4, L6 to L9), and secondary forest (L5) (Figure 1). Five sites per LUU were sampled. In each site, 1-3 largest trees were selected for sampling. Narrow frequency grids $(10 \mathrm{~cm} \times 50 \mathrm{~cm})$, each divided into 5 sampling unit of $10 \mathrm{~cm} \times 10 \mathrm{~cm}$, were used for lichen sampling in each tree (Scheidegger et al. 2002; Rai et al. 2011). The number of grids per tree varied from 1 to 3 depending upon tree size. Such grids were laid from the bottom of tree to the breast height. Lichen diversity at each phorophyte and location of phorophyte in the forest was recorded. Circumference at breast height $(\mathrm{CBH})$ was taken as measure of stand age of phorophytes. Locations (coordinates) and elevation were recorded using hand-held GPS unit (Garmin GPSmap 76S).

Collected lichen samples were examined and identified at Lichenology Laboratory, National Botanical Research Institute, Lucknow, Uttar Pradesh, India. Lichens were identified using a stereomicroscope, and light microscope morphoanatomically and chemically with the help of spot tests, UV light and standardized thin-layer chromatography (Elix and Ernst-Russel 1993; Orange et al. 2001). Identification of lichens was further checked in relevant keys and monographs (Ahti 2000; Awasthi 2007; Saag et al. 2009). Collected specimens were deposited at the Lichen Herbarium (LWG), National Botanical Research Institute (NBRI), Lucknow, Uttar Pradesh, India. The current study reports lichens sorted and grouped up to generic level as the samples are still due for HPLC analysis for further identification/confirmation up to species level.

\section{DATA ANALYSIS}

Epiphytic lichen assemblage was quantitatively analyzed for frequency, with reference to lichen richness (number of lichen genera) on phorophytes and growth form diversity in the ten LUUs (Curtis and McIntosh 1950; Pinokiyo et al. 2008; Rai et al. 2011). Indirect gradient ordination method, principal component analysis (PCA), was used to determine the component in the lichen-phorophyte complex determining the whole community (Gauch 1982; ter Braak and Prentice 1988). Epiphytic lichen clusters were defined through hierarchical cluster analysis (Ludwig and Reynolds 1988; Jongman et al. 1995) using Bray-Curtis distances and unweighted pair-group moving average (UPGMA) on the basis of generic frequency of epiphytic lichens on phorophytes. Both PCA and cluster analysis, were performed using multivar option in PAST 2.09 (Hammer et al. 2001; Hall 2005; Rai et al. 2011).

\section{Results}

\section{AVERAGE COMMUNITY STRUCTURE AND PATTERNS}

Total 27 epiphytic lichen genera belonging to 13 families were recorded from ten LUUs of the Dadeldhura CF (Table 1). Parmeliaceae was the dominant family, followed by Physciaceae and Ramalinaceae as primary co-dominant families, and Caliciaceae and Arthoniaceae as secondary codominant families (Figure 3). Five lichen growth forms crustose, leprose, foliose, fruticose and dimorphic (squamules as primary thallus bearing erect fruticose body as secondary thallus) - were encountered in the landscape (Table 1). There were considerable differences in generic constitution and abundance of epiphytic lichens among phorophytes. Quercus leucotrichophora harbored the highest number of lichen (23 genera) with high total frequency $(72.17 \%)$, followed by Rhododendron arboreum (8 genera and frequency of 11.14\%), Pinus roxburghii (7 genera and frequency of $7.27 \%$ ) and Myrica esculenta (7 genera and frequency of 9.42\%) (Table 1).

Among the various LUU types studied, primary forests harbored the highest number of epiphytic lichen genera (2838) (Table 2). Foliose lichen diversity and abundance (in terms of frequency) increases from the fringes of the forest to the core. LUUs having primary forest harbor highest diversity of foliose growth forms (Table2).

The CBH data showed that vegetation stands of all the phorophytes were distributed randomly in LUUs of Dadeldhura CF (Figure 4, Table 2). 


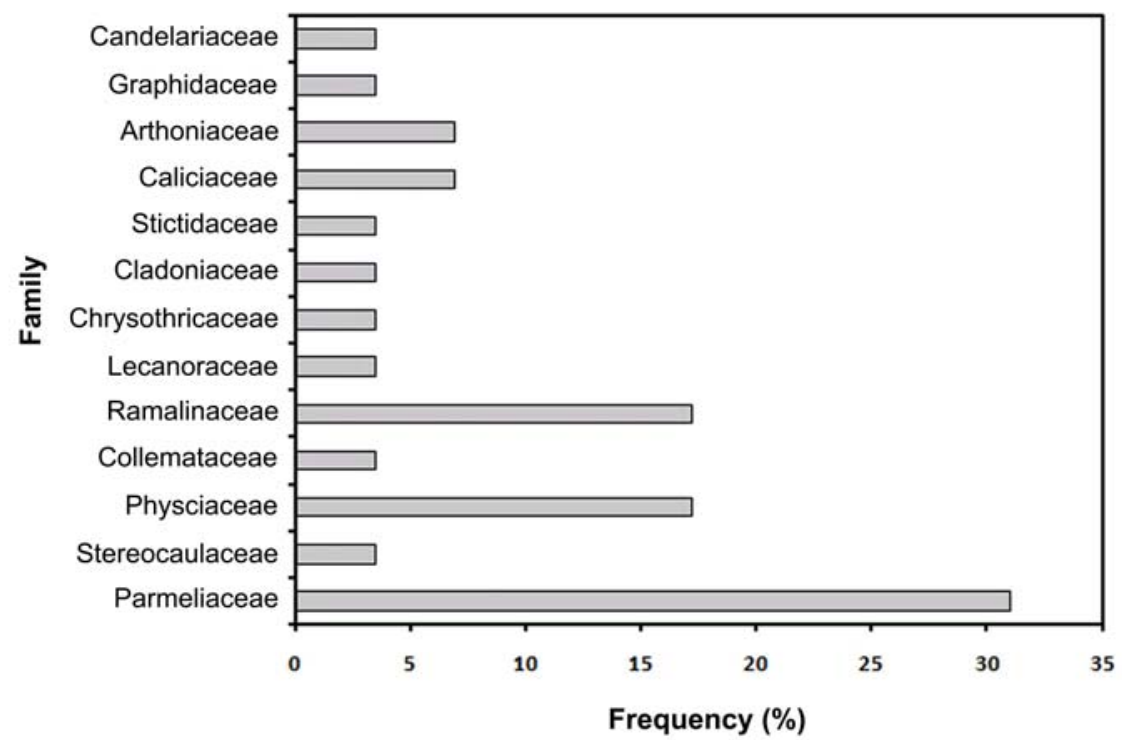

Figure 3. Family diversity of epiphytic lichens recorded from Dadeldhura Community Forest.

Table 2. Generic diversity and frequency of epiphytic (corticolous) lichen growth forms and phorophyte stand size distribution (based on (CBH) in various land-use units (LUUs) of Dadeldhura CF.

\begin{tabular}{|c|c|c|c|c|c|c|c|c|c|c|c|c|}
\hline \multirow[t]{2}{*}{ LUU } & \multirow[t]{2}{*}{ LUU type } & \multicolumn{7}{|c|}{ Generic diversity and frequency (\%) of epiphytic lichen growth forms* } & \multicolumn{4}{|c|}{ Phorophyte ${ }^{\dagger} \mathrm{CBH}^{\ddagger}(\mathrm{cm})$} \\
\hline & & $\mathrm{Cr}$ & Lp & Fo & $\mathrm{Fr}$ & $\mathrm{Dm}$ & So & $\begin{array}{c}\text { Total } \\
\text { genera } \\
\text { recorded }\end{array}$ & Ql & $\mathrm{Ra}$ & $\operatorname{Pr}$ & $\mathrm{Me}$ \\
\hline L1 & $\begin{array}{l}\text { Human } \\
\text { settlements }\end{array}$ & $\begin{array}{c}2 \\
(40.0)\end{array}$ & $\begin{array}{c}2 \\
(40.0)\end{array}$ & $\begin{array}{c}1 \\
(20)\end{array}$ & - & - & - & 5 & 35.8 & - & - & 31.0 \\
\hline L2 & $\begin{array}{l}\text { Fringe } \\
\text { forests }\end{array}$ & $\begin{array}{c}4 \\
(17.4)\end{array}$ & $\begin{array}{c}3 \\
(13.0)\end{array}$ & $\begin{array}{c}16 \\
(69.5)\end{array}$ & - & - & - & 23 & 59.7 & 47.4 & 49.3 & - \\
\hline L3 & $\begin{array}{l}\text { Agricultural } \\
\text { Fields }\end{array}$ & $\begin{array}{c}9 \\
(81.8)\end{array}$ & $\begin{array}{c}1 \\
(9.1)\end{array}$ & $\begin{array}{c}1 \\
(9.1)\end{array}$ & - & - & - & 11 & 23.7 & - & 56.0 & 33.7 \\
\hline L4 & $\begin{array}{l}\text { Primary } \\
\text { forests }\end{array}$ & $\begin{array}{c}4 \\
(10.5)\end{array}$ & $\begin{array}{c}4 \\
(10.5)\end{array}$ & $\begin{array}{c}29 \\
(76.3)\end{array}$ & - & - & $\begin{array}{c}1 \\
(2.6)\end{array}$ & 38 & 25.3 & - & - & - \\
\hline L5 & $\begin{array}{l}\text { Secondary } \\
\text { forest }\end{array}$ & $\begin{array}{c}6 \\
(42.8)\end{array}$ & $\begin{array}{c}2 \\
(14.3)\end{array}$ & $\begin{array}{c}3 \\
(21.4)\end{array}$ & $\begin{array}{c}2 \\
(14.3)\end{array}$ & - & $\begin{array}{c}1 \\
(7.1)\end{array}$ & 14 & 48.7 & 76.7 & 53.0 & 31.3 \\
\hline L6 & $\begin{array}{l}\text { Primary } \\
\text { forests }\end{array}$ & $\begin{array}{c}3 \\
(7.9)\end{array}$ & $\begin{array}{c}5 \\
(13.2)\end{array}$ & $\begin{array}{c}26 \\
(68.4)\end{array}$ & $\begin{array}{c}4 \\
(10.8)\end{array}$ & - & - & 38 & 59.3 & - & - & - \\
\hline L7 & $\begin{array}{l}\text { Primary } \\
\text { forests }\end{array}$ & $\begin{array}{c}2 \\
(5.5)\end{array}$ & $\begin{array}{c}4 \\
(11.1)\end{array}$ & $\begin{array}{c}26 \\
(72.2)\end{array}$ & - & - & $\begin{array}{c}4 \\
(11.1)\end{array}$ & 36 & 51.5 & 44.0 & 55.0 & 32.3 \\
\hline L8 & $\begin{array}{l}\text { Primary } \\
\text { forests }\end{array}$ & $\begin{array}{c}1 \\
(3.6)\end{array}$ & $\begin{array}{c}5 \\
(17.8)\end{array}$ & $\begin{array}{c}22 \\
(78.5)\end{array}$ & & - & - & 28 & 43.7 & - & - & - \\
\hline L9 & $\begin{array}{l}\text { Primary } \\
\text { forests }\end{array}$ & $\begin{array}{c}2 \\
(6.1)\end{array}$ & $\begin{array}{c}6 \\
(18,2)\end{array}$ & $\begin{array}{c}22 \\
(66.7)\end{array}$ & - & - & $\begin{array}{c}3 \\
(9.1)\end{array}$ & 33 & 53.1 & 49.7 & - & 28. 7 \\
\hline L10 & $\begin{array}{l}\text { Fringe } \\
\text { forests }\end{array}$ & $\begin{array}{c}2 \\
(9.5)\end{array}$ & $\begin{array}{c}2 \\
(9.5)\end{array}$ & $\begin{array}{c}3 \\
(14.3)\end{array}$ & $\begin{array}{c}1 \\
(4.7)\end{array}$ & $\begin{array}{c}13 \\
(61.9)\end{array}$ & - & 21 & 47.8 & 39.3 & 49.3 & - \\
\hline
\end{tabular}

*Growth forms of epiphytic lichens: $\mathrm{Cr}=$ Crustose, $\mathrm{Lp}=$ leprose, $\mathrm{Fo}=$ foliose, $\mathrm{Fr}=$ fruticose, $\mathrm{Dm}=$ dimorphic, $\mathrm{So}=$ sorediate. Values in parentheses are generic frequency for each growth form categories in each LUU.

${ }^{+}$Phorophytes, $\mathrm{Ql}=$ Quercus leucotrichophora, $\mathrm{Ra}=$ Rhododendron arboretum, $\mathrm{Pr}=$ Pinus roxburghii, $\mathrm{Me}=$ Myrica esculenta .

‡ Circumference at breast height, reported values are arithmetic mean. 


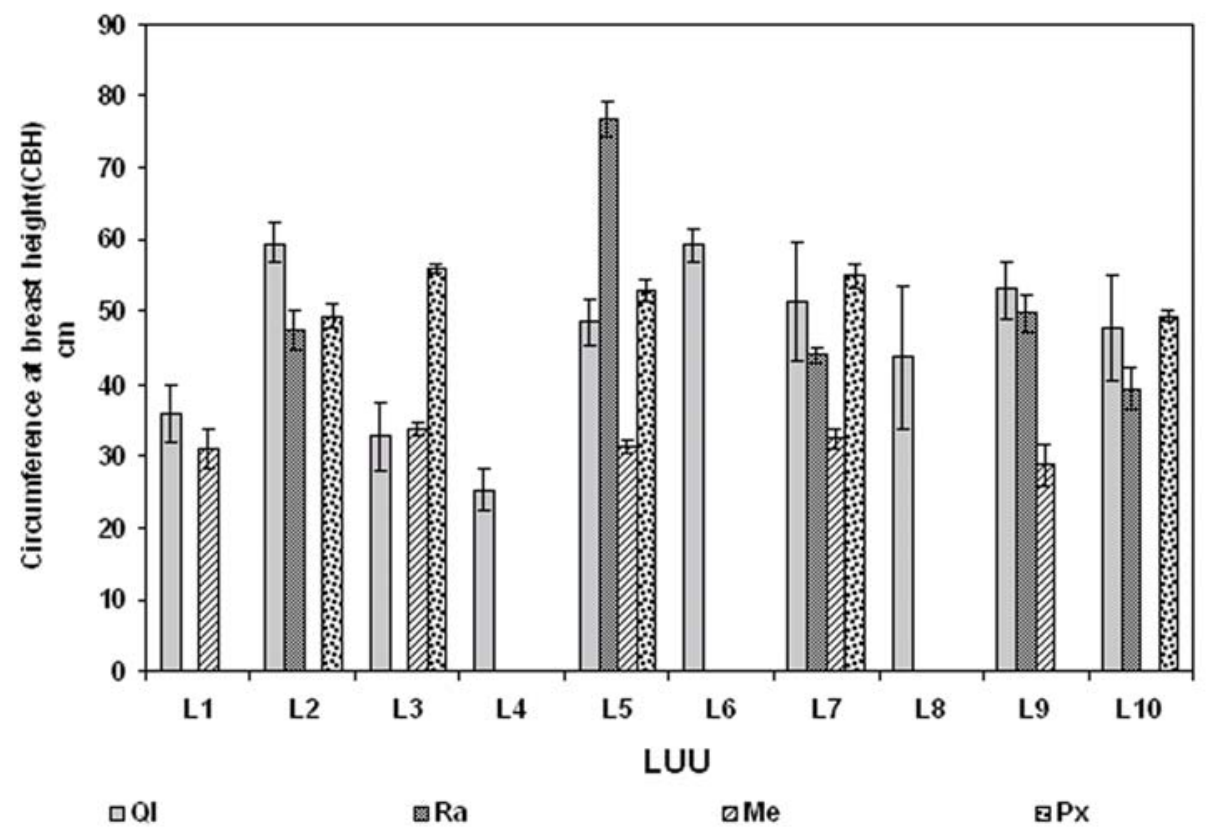

Figure 4. Circumference at breast height (CBH) of different phorophytes recorded in the ten LUUs of Dadeldhura Community Forest, Ql - Quercus leucotrichophora; Ra - Rhododendron arboreum; Me - Myrica esculenta; Px - Pinus roxburghii. Values are reported as mean $\pm \mathrm{SE}$.

\section{PRINCIPAL COMMUNITY DETERMINANTS}

The PCA analysis required 4 components (axis) to account for $100 \%$ variation in the data set. PCA axes 1 and 2 explained $93 \%$ and $4 \%$ variance respectively. Majority of the epiphytic lichens in Dadeldhura CF were found influenced by Quercus leucotrichophora (Figure 5), which was the dominant phorophyte. The PCA shows that some lichen genera, such as Heterodermia spp., Parmotrema spp., Lepraria spp. and Lecanora spp., were highly confined to Q. leucotrichophora. Although these lichen genera have maximum frequency distribution on Q. leucotrichophora, they were also distributed on other phorophytes (Table 1). Few genera, particularly Cladonia, Ramalina and Candelaria were exclusively confined to phorophytes other than $Q$. leucotrichophora (Figure 5 and Table 1).

Cluster analysis further strengthened the findings of PCA, where two major groups of lichen could be defined, one having their maximum distribution on Q. leucotrichophora (Group II) and the second having their maximum distribution on other phorophytes (Group I). These groups were divided into minor clusters on the basis of their degree of distribution on the three phorophytes (Figure 6, Table 1).

\section{Discussion}

Dadeldhura CF harbors typical elements of temperate forest of central west Himalayas (Negi 2000). Temperate vegetation elements, like Quercus, Pinus and Rhododendron influence the overall epiphytic lichen vegetation of the area. Land-use patterns are also known to affect the lichen diversity (Motiejûnaitë and Faùtynowicz 2005). The low diversity of epiphytic lichens in the fringe forest and high diversity in the primary forests confined to the core of the Dadeldhura CF can be attributed to the human disturbance. There was decreasing level of disturbance from fringes to the core of the forest. However, the absence of any consistence pattern of stand age of phorophytes (measured as $\mathrm{CBH}$ ) in different forests indicates unconstrained and unsustainable selection cutting of forest resources. Selective cutting of phorophytes is the major disturbance affecting the distribution of lichens (Edman et al. 2008). Although selective cutting of phorophyte was high in the fringes of Dadeldhura CF, greatly affecting the distribution of lichen genera, the core of the forest is also not intact as depicted by $\mathrm{CBH}$ data.

The preferential distribution of lichens on Quercus leucotrichophora is indicative of dominant status of this tree 


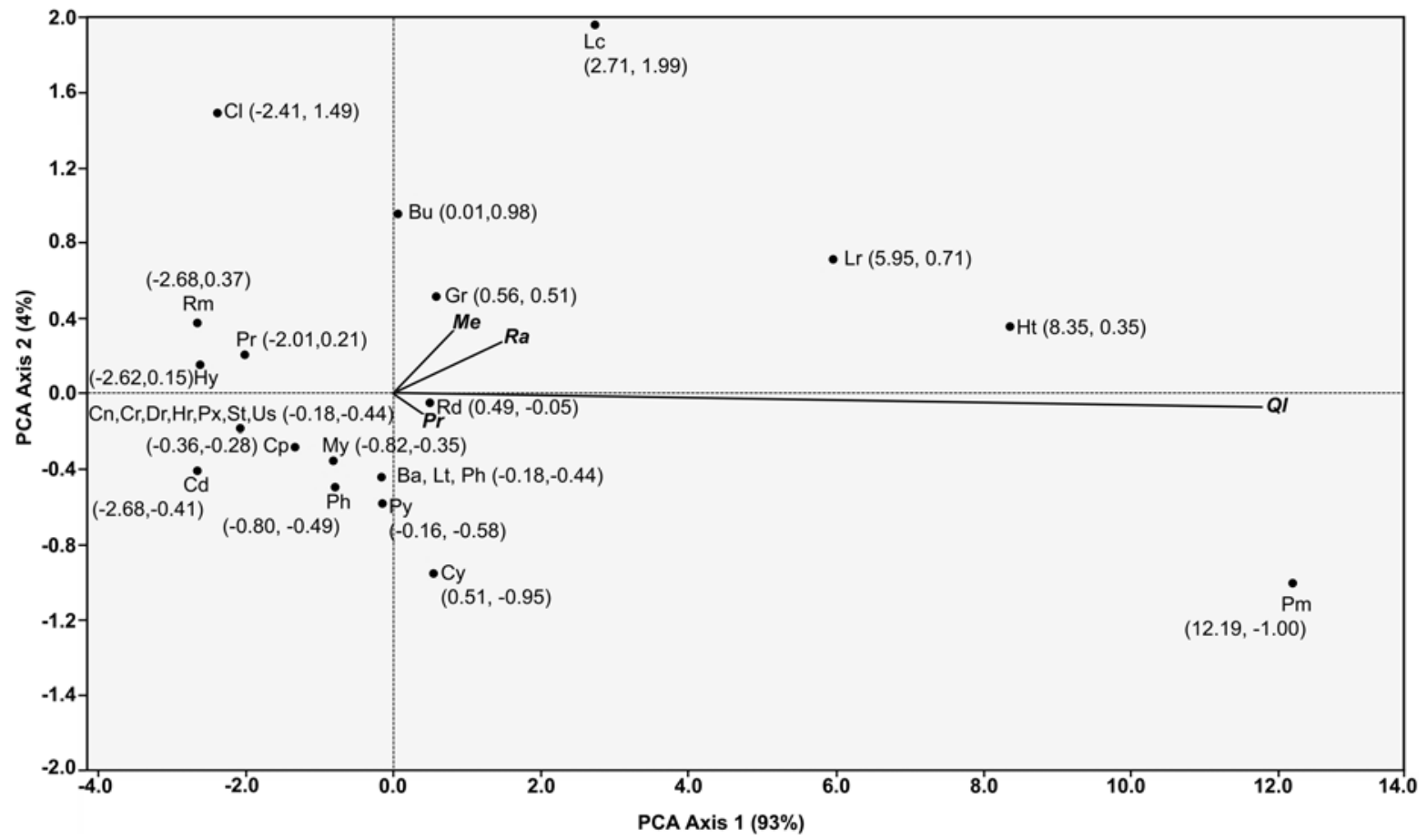

Figure 5. PCA ordination biplot of epiphytic lichens of Dadeldhura Community Forest. Values in parentheses are PC axis scores for axis 1 and 2 (See Table 1 for abbreviations).

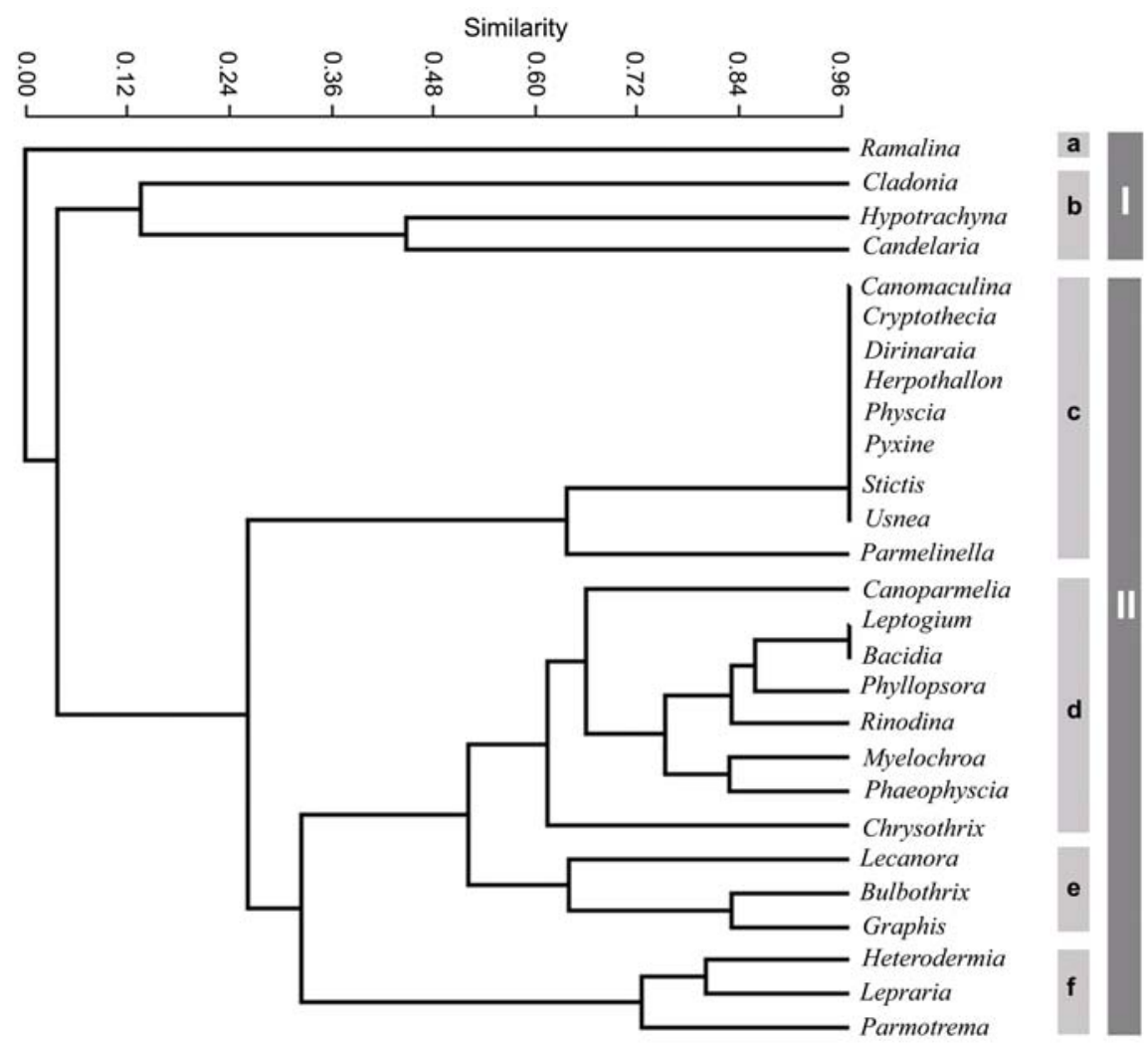

Figure 6. Groups of epiphytic lichens resulting from hierarchical cluster analysis based on their distribution on different phorophytes. 
species and its lichen-supporting bark characteristics (e.g. $\mathrm{pH}$, roughness and water retention capacity). Among the various growth forms, foliose (i.e. parmeloid lichens) is considered as most sensitive to land-use changes (Saipunkaew et al. 2007). In the present study, diversity of foliose lichen increased towards the core in primary forests receiving comparatively low anthropogenic disturbance (Table 1).

Community forest in western Nepal harbors rich diversity of epiphytic lichens. Lichen and other lower group of organisms are generally ignored in community forest management practice. The study indicates that epiphytic lichens in general and foliose growth form in particular can be used as indicators of land-use change and overall forest health in community forests. Integration of lichens in the community forest management operation plan would enhance the forest monitoring and overall management system.

\section{Acknowledgements}

Authors are grateful to Campus Chief of Mahendra Multiple Campus, Tribhuvan University, Nepalgunj, Nepal; the head of Department of Botany, Mahendra Multiple Campus (TU), Nepalgunj, Nepal and Director, National Botanical Research Institute, Lucknow and University Grant Commission, India for providing necessary laboratory facilities and financial assistance for the work. This research is dedicated to late Dr. D.D Awasthi (Sept. 28, 1922- Aug. 21, 2011), a pioneer lichenologist, whose works laid foundation for systematic lichenological research in the Indian subcontinent.

\section{References}

Agrawal A. and Gibson C.C. 1999. Enchantment and disenchantment: the role of community in natural resource conservation. World Development 27: 629-649.

Ahti T. 2000. Cladoniaceae. Flora neotropica monograph 78. The New York Botanical Garden Press, New York, USA.

Awasthi D.D. 2007. A compendium of the macrolichens from India, Nepal and Sri Lanka. Bishen Singh Mahendra Pal Singh, Dehradun, India.

Berkes F. 2007. Community-based conservation in a globalized world. Proceeding of Natural Academy of Science 104: 15188-15193.

Curtis J.T. and McIntosh R.P.1950. The interrelations of certain analytic and synthetic phytosociological characters. Ecology 31: 434-455.
Dougill A.J., Soussan J.G., Kiff E., Springate-Bagniski O., Yadav N.P., Dev O.P. and Hurford A.P. 2001. Impact of community forestry on farming system sustainability in the middle hills of Nepal. Land Degradation and Development 12: 261-276.

Edman M., Erikson A. and Villard M. 2008. Effect of selection cutting on the abundance and fertility of indicator lichens Lobaria pulmonaria and Lobaria quercizans. Journal of Applied Ecology 45: 26-33.

Elix J.E. and Ernst-Russel K.D. 1993. A Catalogue of Standardized Thin Layer Chromatographic Data and Biosynthetic Relationships for Lichen Substances. $2^{\text {nd }}$ ed. Australian National University, Canberra, Australia.

Gauch H.G., Jr. 1982. Multivariate Analysis in Community Ecology. Cambridge University Press, Cambridge, USA.

Hall A. 2005. The Environmental Gradients and Plant Communities of Bergen Swamp, N.Y., U.S.A. MS Thesis, Rochester Institute of Technology, Rochester, New York, USA. [Online] URL: https://ritdml.rit.edu/bitstream/handle/ 1850/1121/AHallThesis2005.pdf?sequence $=8$.

Hammer $\varnothing$, Harper D.A.T. and Ryan P.D. 2001. PAST: paleontological statistics software package for education and data analysis. Palaentologia Electonica 4(1):9 [online] URL: http://palaeo-electronica.org/2001_1/past/issue1 01.htm.

Jongman R.H.G., ter Braak C.J.F. and van Tongeren O.F.R. eds. 1995. Data Analysis in Community and Landscape Ecology. Cambridge University Press. Cambridge, USA.

Ludwig J.A. and Reynolds J.F. 1988. Statistical Ecology: A Primer of Methods and Computing. John Wiley \& Sons, New York, USA.

Motiejûnaitë J. and Faùtynowicz W. 2005. Effect of land-use on lichen diversity in the transboundary region of Lithuania and northeastern Poland. Ekologija 3: 34-43.

Negi H.R. 2000. On the patterns of abundance and diversity of macrolichens of Chopta-Tungnath in Garhwal Himalaya. Journal of Biosciences 25: 367-378.

Nimis P.L., Scheidegger C. and Wolseley P.A., eds. 2002. Monitoring with Lichen: Monitoring Lichens. Kluwer Academic Publishers, Dordredht.

Orange A., James P.W. and White F.J. 2001. Microchemical Methods for the Identification of Lichens. British Lichen Society, London, UK.

Pinho P., Augusto S., Máguas C., Pereira M.J., Soares A. and Branquinho C. 2008. Impact of neighbourhood land-cover in epiphytic lichen diversity: analysis of multiple factors working at different special scales. Environmental Pollution 151: 414-422.

Pinokiyo A., Singh K.P. and Singh J.S. 2008. Diversity and distribution of lichens in relation to altitude within a protected biodiversity hot spot, north-east India. The Lichenologist 40: 47-62.

Rai H., Upreti D.K. and Gupta R.K. 2011. Diversity and distribution of terricolous lichens as indicator of habitat heterogeneity and grazing induced trampling in a temperatealpine shrub and meadow. Biodiversity and Conservation (in press). DOI 10.1007/s10531-011-0168-z.

Saag L., Saag A. and Randlane T. 2009. World survey of the genus Lepraria (Stereocaulaceae, lichenized Ascomycota). The Lichenologist 41: 25-60. 
Saipunkaew W., Wolseley P. and Chimonides P.J. 2005. Epiphytic lichens as indicators of environmental health in the vicinity of Chang Mai city, Thailand. The Lichenologist 37: 345-356.

Saipunkaew W., Wolseley P.A., Chimonides P.J. and Boonpragob K. 2007. Epiphytic macrolichens as indicators of environmental alteration in northern Thailand. Environmental Pollution 146: 366-374.

Scheidegger C., Groner U., Keller C. and Stoffer S. 2002. Biodiversity assessment tools - lichens. In: Monitoring with Lichens: Monitoring Lichens (P.L. Nimis, C. Scheidegger and P.A.Wolseley, eds), pp. 459-365. Kluwer Academic Publishers, Dordredht, Netherlands.

Stofer S., Bergamini A.,Araón G., Carvalho P., Coppins B.J., Davey S., Dietrich M., Farkas E., Kärkkäinen K., Keller C., Lökös L., Lommi S., Máguas C., Mitchell R., Pinho P., Rico V., Truscott A., Wolseley P.A., Watt A. and Scheidegger C. 2006. Species richness of lichen functional groups in relation to land use intensity. The Lichenologist 38: 331-353.

ter Braak C.J.F. and Prentice I.C. 1988. A theory of gradient analysis. Advances in Ecological Research 18: 271-313.

Thomas R., Per J., Niclas B. and Mats N. 2008. The influence of tree age and microhabitat quality on the occurrence of crustose lichens associated with old oaks. Journal of vegetation science 19: 653-662.

Will-Wolf S., Esseen P.A. and Neitlich P. 2002a. Monitoring biodiversity and ecosystem function: Forests. In: Monitoring with Lichens-Monitoring Lichens (P.L. Nimis, C. Scheidegger and P.A. Wolseley, eds.), pp. 165-176. Kluwer Academic Publishers, Dordredht, Netherlands.

Will-Wolf S., Scheidegger C. and McCune B. 2002b. Methods for monitoring biodiversity and ecosystem function. In: Monitoring with Lichens-Monitoring Lichens (P.L. Nimis, C. Scheidegger and P.A. Wolseley, eds.), pp. 146-162. Kluwer Academic Publishers, Dordredht, Netherlands. 